\title{
Effect of Nursing Guidelines on Minimizing Postoperative Complications for Patients with Abdominal Bariatric Surgeries
}

\author{
Heba Gomaa El-dawoody, Osama Yaseen Taha, Ghona Abed EL-naser Ali \& Sahra Zaki Azer. \\ Demonstrator in Adult Nursing Department, Faculty of Nursing, Sohag University, Egypt. \\ Professor in Plastic Surgery Department, Faculty of Medicine, Assiut University, Egypt. \\ Assistant Professor in Adult Nursing Department, Faculty of Nursing ,Sohag University, Egypt. \\ Lecturer in Adult Nursing Department, Faculty of Nursing, Assiut University, Egypt.
}

\begin{abstract}
Background, Bariatric surgery includes a variety of procedures performed on people who have obesity. The study aimed to investigate the impact of nursing guidelines among bariatric surgery patients on minimizing the postoperative complications for patients with bariatric surgery. Research design, Quasi-experimental research design was utilized in this study. Sample, the study was conducted on a convenient sample of 50 adult patients with bariatric surgery who selected randomly (25 - study group and 25 - control group). Setting, data were collected from plastic surgery department at Assiut University Hospital. Tools, data were collected through two tools; patient informational assessment sheet and postoperative complications follow up sheet. Results, this study concluded that more than half of the sample in the study group were females. While the majority of the sample in control group 92\% were females and $52.0 \%$ were married. There was statistically significant difference as regarded pre and postoperative score for level of knowledge of study group about bariatric surgery except important of the efficiency of vital signs, knowledge about postoperative complications, an exercise carried out and good diet after the operation. Conclusion, there were significant differences improvements throughout the implementation of nursing guidelines among the study group. Recommendation, the study recommended that pamphlets and simple illustration booklet should be available for patients illiterate to with simple explain how to safely live after bariatric surgery.
\end{abstract}

\section{Keywords: Guidelines, Postoperative complications, Nursing \& Bariatric surgery}

\section{Introduction}

Obesity is defined as abnormal or excessive fat accumulation that presents a risk to health. A crude population measure of obesity is the body mass index (BMI), a person's weight (in kilograms) divided by the square of his or her height (in meters). A person with a BMI of 30 or more is generally considered obese. A person with a BMI equal to or more than 25 is considered overweight (Ogden et al., 2012).

Bariatric surgery (weight loss surgery) is a procedure that makes changes to the digestive system to help lose weight by limiting how much you can eat or by reducing the absorption of nutrients, or both. Bariatric surgeries are done when diet and exercise haven't worked or when patients have serious health problems because of obesity (Arterburn et al., 2015). Indications of bariatric surgery include; BMI greater than 40; BMI between 35 and 40 associated with significant comorbidity: hypertension, diabetes, degenerative joint disease or arthritis, sleep apnea (Noria, 2013).Contraindications of bariatric surgery; an uncontrolled psychiatric disorder such as major depression, current drug, alcohol abuse, cancer that is not in remission and inability to comply with nutritional requirements, including lifelong vitamin replacement (when indicated) (Pepino et al., 2014).
Classification of bariatric surgical procedures; weight loss operations fall into three categories; restrictive, malabsorptive and mixed procedures. Restrictive procedures are solely restrictive act to reduce oral intake by limiting gastric volume, produce early satiety, and leave the alimentary canal in continuity and minimizing the risks of metabolic complications. Restrictive procedures include vertical banded gastroplasty, adjustable gastric band, sleeve gastrectomy, the intragastric balloon (gastric balloon) and gastric placation. Malabsorptive procedures, although they also reduce stomach size, the effectiveness of these procedures is derived mainly from creating a physiological condition of malabsorption. Malabsorptive procedures include biliopancreatic diversion and jejunoileal bypass. Combination (mixed) procedures employ both restriction and malabsorption which include: gastric bypass surgery, sleeve gastrectomy with duodenal switch and implantable gastric stimulation (Horwitz et al., 2015).

anastomotic leak or intestinal obstruction may not be easy to diagnose because of the patient's large abdomen .Thus, there should be a low threshold for 
ordering a barium radiograph or computed tomogram. Endoscopy is rarely indicated at this time.Late complications; in describing the nursing care of the bariatric-surgery patient defines late complications as those which occur once the patient has been discharged from the hospital and has recovered from the surgery. These complications can be further classified according to the surgical procedure performed. The euphoria induced by weight loss in bariatric patients may be replaced by disappointment and regret with the development of new gastrointestinal tract symptoms and complications. Some nutritional, hepatobiliary, luminal, and functional complications are more likely after specific bariatric procedures(O'Brien et al., 2013).

General guidelines of post bariatric surgery diet eat balanced meals with small portions, follow a diet low in calories, fats and sweets, keep a daily record of food portions and of calories and protein intake, eat slowly and chew small bites of food thoroughly, avoid rice, bread, raw vegetables and fresh fruits, as well as meats that are not easily chewed, such as pork and steak. Ground meats are usually better tolerated, do not use straws, drink carbonated beverages or chew ice. They can introduce air into pouch and cause discomfort, avoid sugar, sugar-containing foods and beverages, concentrated sweets and fruit juices, for the first two months following surgery, calorie intake should be between 300 and 600 calories a day, with a focus on thin and thicker liquids, daily caloric intake should not exceed 1,000 calories (Contreras et al., 2013).

Exercise plane after bariatric surgery, Develop and maintain a consistent exercise program to strengthen heart and bones, burn calories, develop muscles, increase metabolic rate, improve mood and relieve stress. Exercising can also improve blood sugar control. Walking is an excellent exercise that patient can begin immediately after surgery. Start by walking 10 minutes a day. Increase walk by one minute every few days. Remember, exercise needs to increase heart rate, so gardening does not count. It is also recommended to add strength training to build and maintain muscle mass, but please do not start strength training until at least six weeks after surgery. It is important to allow incisions to heal first. The patient must be keep in mind that you may not lose weight if not exercising (Marquez et al., 2015).

\section{Significance of the study}

This study is the first study in this field. The study can also open in the development of the study of minimizing postoperative complications for a patient with bariatric surgery. According to the international study, bariatric surgery complications affect about $15 \%$ of patients annually. Complications range from minor to severe and could be a single event or chronic in nature. This research will help health care team to minimize the risks of complications associated with each type of weight loss surgery(Mechanick et al., 2010).

\section{Aim of the Study}

This study aims to

- Assess knowledge of patient about bariatric surgery and nursing guideline.

- Develop nursing guidelines for patients with bariatric surgery.

- Evaluate the effect of nursing guidelines on knowledge and postoperative complications of patients with bariatric surgery.

\section{Hypothesis}

To fulfill the aim of the study the following research hypothesis were formulated

- The knowledge of the study group bariatric patients after application of the nursing guidelines is more than knowledge of control group.

- The postoperative complications of patients with bariatric surgery are minimized in the study group than control group.

\section{Research design}

Quazi experimental research design was utilized to conduct data of this study.

\section{Setting}

The study was conducted in the plastic surgical department at Assiut University Hospitals.

\section{Subjects}

A purposive sample of available patients (50). The samples were divided into two equal groups, 25 study group who received nursing guidelines and 25 control group who received routine hospital care(male and female).

\section{Sampling}

The sample size was calculated using the sample size equation. Sample size was estimated with statistical program (Mini tab 17) and determined according to this equation as follow:

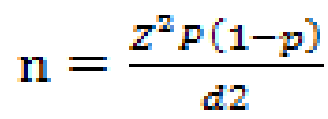

- $\mathrm{n}=$ required sample size

- $\mathrm{Z}=$ confidence level (1.96)

- $\mathrm{d}=$ margin of error 0.5

- $\mathrm{p}=0.5$

$\mathrm{n}$ : according to equation, it was equal to $=348$ note: selecting 50 patient depended on the decreasing number of patients undergoing bariatric surgery per 
month in Assuit university hospitals (abut 7 cases monthly).

The tools were tested for content validity by 5 experts of (2 academic Plastic Surgery staff and 3 nursing staff from faculty of Nursing) at Assuit University who reviewed the tools for clarity, relevance, comprehensiveness, and understanding. Minor modifications were required and correction was carried out accordingly. Then the final form of the tool was designed and tested for reliability by using internal consistency for the tools measured using Cronbach test, the tools proved to be reliable (0.73).

\section{Inclusion criteria}

- Age between (18-65) years old.

- Patients with BMI >40.

- Patients with BMI=35with serious coexisting medical conditions related to obesity as sleep apnea and chronic obstructive pulmonary disease.

\section{Study tools}

Two tools were used for investigate the impact of nursing guidelines on minimizing postoperative complications after bariatric surgery.

Tool 1: Patient informational assessment sheet:this tool was developed by the researcher and used to assess the informational needs of patients in study and control groups, it included two parts:

Part 1: it included the demographic and clinical data of patients under study; name, age, gender, level of education, marital status, occupation, type of surgery and type of wound, height, weight, body mass index and chronic diseases such as coronary artery disease, diabetes mellitus types $1 \& 2$, chronic renal failure and cardiac failure.

Part 2: it includes 11 questions about definition of bariatric surgery, indications, contraindications, preoperative instructions, radiological and laboratory investigations, postoperative complications, preoperative preparation, postoperative diet and exercise, pre\&postoperative care and instructions on discharge after bariatric surgery.

\section{Total scoring system of tool (1):}

Patient assessment knowledge about bariatric surgery which includes 11 questions, each question was observed, categorized, and scored into either know $=1$ or don't know $=0$ on all questions.

Tool 2: Postoperative complications follow up sheet; it was developed by the researcher to assess complications and patient outcome. Is the follow after $1^{\text {st }}, 2^{\text {nd }}$, and $6^{\text {th }}$ months.

anastomotic leak or intestinal obstruction may not be easy to diagnose because of the patient's large abdomen .Thus, there should be a low threshold for ordering a barium radiograph or computed tomogram. Endoscopy is rarely indicated at this time.Late complications; in describing the nursing care of the bariatric-surgery patient defines late complications as those which occur once the patient has been discharged from the hospital and has recovered from the surgery. These complications can be further classified according to the surgical procedure performed. The euphoria induced by weight loss in bariatric patients may be replaced by disappointment and regret with the development of new gastrointestinal tract symptoms and complications. Some nutritional, hepatobiliary, luminal, and functional complications are more likely after specific bariatric procedures (O'Brien et al., 2013).

\section{Nursing guidelines for bariatric surgery}

It was developed by the researcher based on the review of the relevant literature and available resource. It includes three parts:

\section{Part 1: Information to the patient about}

Definition, indications, contraindications, preoperative instructions, radiological and laboratory investigations, postoperative complications, preoperative preparation, postoperative diet and exercise, pre \& postoperative care and instructions on discharge after bariatric surgery.

Part 2: Patient diet; Information about diet which included:

Eat balanced meals with small portions, follow a diet low in calories, fats and sweets, keep a daily record of food portions and of calories and protein intake, eat slowly and chew small bites of food thoroughly, avoid rice, bread, raw vegetables and fresh fruits, as well as meats that are not easily chewed, such as pork and steak. Ground meats are usually better tolerated, do not use straws, drink carbonated beverages or chew ice. They can introduce air into pouch and cause discomfort, avoid sugar, sugar-containing foods and beverages, concentrated sweets and fruit juices, for the first two months following surgery, calorie intake should be between 300 and 600 calories a day, with a focus on thin and thicker liquids, daily caloric intake should not exceed 1,000 calories (Contreras et al., 2013).

Estimate the balanced meal equation by the following:

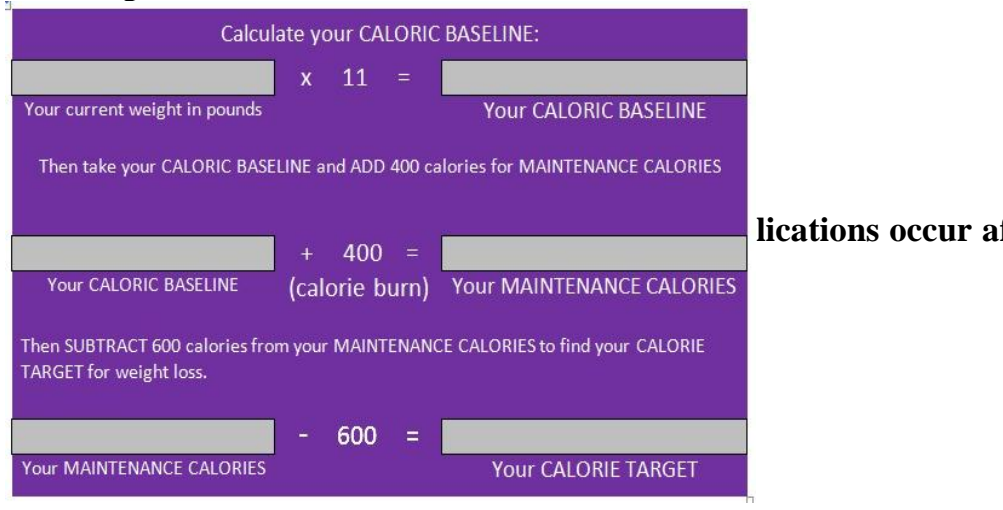


Fig (1): adopted from (Contreras, et al., 2013). Part 3: Patient exercise:

Exercise is recommended for success in achieving and maintaining weight loss. Develop and maintain a consistent exercise guidelines to strengthen heart and bones, burn calories, develop muscles, increase metabolic rate, improve mood and relieve stress. Exercising can also improve blood sugar control as walking, aerobic exercise, and strength training.

\section{Description of the nursing guidelines}

Postoperative bariatric surgery guidelines

The guidelines consist of three phases; preparatory phase (assessment and planning phase), implementation phase; this phase comprised the preoperative, postoperative and during this phase exercise training guidelines and diet were implemented and follow-up phase (evaluation phase). The nursing guidelines were designed to minimize the postoperative complications of bariatric surgery through individualized sessions. It developed by the researcher based on the review of relevant literature, available resources, and the patient needs assessment. A number of sessions; a total (3) sessions was conducted for each patient in addition to the preassessment session. Preparing of guidelines training place, teaching aid and media (pictures and Arabic handout); the content of guidelines modified in Arabic language and give it to the patient to help and facilitate the implementation of the guidelines for the patient. The first session included; information about bariatric surgery; definition, indications, contraindications of bariatric surgery. The second session included preoperative instructions, radiological and laboratory investigations and postoperative complications. The third session included; preoperative preparation, postoperative diet, and exercise, pre \&postoperative care and instructions on discharge.

\section{Procedure}

The study was carried out in three phases: $1^{\text {st }}, 2^{\text {nd }}$, and $3^{\text {rd }}$ phases:

Preparatory phase(assessment and planning phase) involved the following: Review of relevant literature; nursing textbooks, journals, internet resources about bariatric surgery. Then content and construct validity for tools were carried out. Patient's agreement for voluntary participation was obtained, the purpose and nature of the study were explained to the patient. A review of current and past, local and international related literature in the various aspects of the problems using books, articles, periodicals, and magazines was done. This phase ended by a pilot study.

\section{Content Validity}

It was established by panel of 5 experts who reviewed the tools for clarity, relevance, comprehensiveness, understanding, easiness for administrative minor modifications were required. The content validity of this tool was checked by expert professors in fields of plastic surgical department and medical surgical nursing and correction were carried out accordingly.

\section{Ethical Consideration}

- Research proposal was approved by ethical committee in the faculty of nursing.

- Informal consent was obtained from patient or guidance that is willing to participate in the study after explaining the nature and purpose of the study.

- Confidentiality of the data was assured.

- Study subject has the right to refuse to participate or withdraw from the study without any rational at any time.

- Study subject privacy was considered during data collection.

\section{Administrative design}

An official permission to conduct the study was obtained by the researcher from the head of plastic surgical department to collect the necessary data after explain the aim of the study to them to obtain their cooperation. Also, the meetings with the patient to explain the objectives and contents of these tools after obtaining the patient consent for this study.

The second phase (implementation phase): This phase comprised the preoperative, postoperative and during this phase, the exercise and diet guidelines were implemented.

\section{Field work phase}

Data were collected at plastic surgical department at Assiut University Hospital during the period from $15 / 8 / 2015$ to $15 / 2 / 2016$. The tools were all filled through interviewing. The purpose of the study was explained to the patients prior to answering the questions. The study was carried out during morning and afternoon shifts for all available patients.

\section{Preoperatively}

Patients were equally enrolled in the study as control and study groups sequentially. The $1^{\text {st }}$ patient's interview was used to explain purpose and nature of the study as well as patient agreement for voluntary participation was obtained.

\section{Postoperatively}

- The interview with study group was at $2^{\text {nd }}$ day postoperatively, and then once time daily during hospitalization for base line data was obtained from study and control groups patients.

- Before discharge, the investigator emphasized the importance of following up visit for all subjects (control and study) and arranged with study group the time and place for follow up which were $1^{\text {st }}, 2^{\text {nd }}$ and $6^{\text {th }}$ week postoperatively in outpatient bariatric surgery clinic at Assiut University Hospitals. 
- Control group patients were exposed to the routine hospital nursing intervention, while study group patients were received preoperative teaching nursing guidelines about diet and exercise after bariatric surgery.

The last phase of proposed guidelines is the evaluation phase. After implementation, the patient knowledge has been evaluated by the researcher by using nursing guideline. A line of contact was established between the investigator and subjects of both groups for feedback, monitoring, and provision of needed consultation and help.

\section{A pilot study}

Carried out in mid August 2015 to evaluate the clarity and applicability of the study tools on groups of 5 patients $(10 \%)$ of the sample. The purpose of the pilot study was to detect any particular problem in the statements clarity, feasibility, and applicability of the tool. The data obtained from the pilot study wear analyzed no change was done in the assessment sheet, so the 5 patients selected for the pilot study were included in the main study.

\section{Statistical design}

Data collected and analyzed by computer program SPSS" ver. 21" Chicago. USA. Data expressed as mean, Standard deviation and number, percentage. Mann-Whitney was used to determine significant for numeric variable. Chi. Square was used to determine significance for categorical variable. Pearson's correlation was used for correlations between groups.

n.s $\mathrm{P}>0.05$ no significant

$* \mathrm{P}<0.05$ significant

$* * \mathrm{P}<0.001$ moderate significance

$* * * \mathrm{p}<0.000$ Highly significance

\section{Results}

Table (1): Distribution of bio-socio-demographic patient's characteristics in study and control group subjects $(\mathbf{n}=\mathbf{5 0})$

\begin{tabular}{|c|c|c|c|c|c|}
\hline \multirow[t]{2}{*}{ Variables } & \multicolumn{2}{|c|}{$\begin{array}{l}\text { Study } \\
n=(25)\end{array}$} & \multicolumn{2}{|c|}{$\begin{array}{c}\text { Control } \\
n=(25)\end{array}$} & \multirow[t]{2}{*}{ P. value } \\
\hline & No. & $\%$ & No. & $\%$ & \\
\hline Age & \multicolumn{2}{|c|}{$35.6+9.5$} & \multicolumn{2}{|c|}{$32.6+6.9$} & $0.221^{\mathrm{ns}}$ \\
\hline BMI & \multicolumn{2}{|c|}{$51.5+6.5$} & \multicolumn{2}{|c|}{$49.4+7.5$} & $0.295^{\mathrm{ns}}$ \\
\hline \multicolumn{6}{|l|}{ Sex } \\
\hline Male & 3 & 12.0 & 2 & 8.0 & \multirow{2}{*}{$0.637^{\mathrm{ns}}$} \\
\hline Female & 22 & 88.0 & 23 & 92.0 & \\
\hline \multicolumn{6}{|l|}{ Marital status } \\
\hline Single & 6 & 24.0 & 10 & 40.0 & \multirow{4}{*}{$0.346^{\mathrm{ns}}$} \\
\hline Married & 16 & 64.0 & 13 & 52.0 & \\
\hline Divorced & 3 & 12.0 & 1 & 4.0 & \\
\hline Widow & 0 & 0.0 & 1 & 4.0 & \\
\hline \multicolumn{6}{|l|}{ Educational level } \\
\hline Illiterate & 0 & 0.0 & 2 & 8.0 & \multirow{2}{*}{$0.149^{\mathrm{ns}}$} \\
\hline Read \& write & 25 & 100.0 & 23 & 92.0 & \\
\hline \multicolumn{6}{|l|}{ Occupation } \\
\hline Work & 12 & 48.0 & 16 & 64.0 & \multirow{2}{*}{$0.254^{\mathrm{ns}}$} \\
\hline Not work & 13 & 52.0 & 9 & 36.0 & \\
\hline
\end{tabular}

T-test used for comparison between means (age, BMI)

Chi-square test used for comparison between percentages (e.g. sex)

${ }^{n s}$ No statistically significant difference $(p>0.05)$ 
Table (2): Pre and postoperative score level of knowledge for patients about bariatric surgery for study group $(\mathbf{n}=\mathbf{5 0})$.

\begin{tabular}{|c|c|c|c|c|c|c|c|c|c|c|c|c|c|}
\hline \multirow{3}{*}{ Variable } & \multicolumn{6}{|c|}{ Pre $(n=25)$} & \multicolumn{6}{|c|}{ Post $(n=25)$} & \multirow{3}{*}{ P. value } \\
\hline & \multicolumn{2}{|c|}{$\mathrm{Cc}$} & \multicolumn{2}{|c|}{ Ince } & \multicolumn{2}{|c|}{ Inc } & \multicolumn{2}{|c|}{$\mathrm{Cc}$} & \multicolumn{2}{|c|}{ Ince } & \multicolumn{2}{|c|}{ Inc } & \\
\hline & No. & $\%$ & No. & $\%$ & No. & $\%$ & No. & $\%$ & No. & $\%$ & No. & $\%$ & \\
\hline $\begin{array}{l}\text { 1. Meaning of } \\
\text { bariatric surgery. }\end{array}$ & - & 0.0 & 9 & 36 & 16 & 64 & - & 0.0 & 25 & 100 & - & 0.0 & $<0.001 * *$ \\
\hline $\begin{array}{l}\text { 2. Indications of } \\
\text { bariatric surgery. }\end{array}$ & - & 0.0 & 1 & 4 & 24 & 96 & 7 & 28 & 14 & 56 & 4 & 16 & $<0.001 * *$ \\
\hline $\begin{array}{l}\text { 3. Contraindications } \\
\text { of bariatric surgery. }\end{array}$ & - & 0.0 & 4 & 16 & 21 & 84 & 15 & 60 & 9 & 36 & 1 & 4 & $<0.001 * *$ \\
\hline $\begin{array}{l}\text { 4. Patient tips should } \\
\text { know before } \\
\text { bariatric surgery. }\end{array}$ & 4 & 16 & 8 & 32 & 13 & 52 & 13 & 52 & 11 & 44 & 1 & 4 & $<0.001 * *$ \\
\hline $\begin{array}{l}\text { 5. Laboratory and } \\
\text { radiological tests } \\
\text { before bariatric } \\
\text { surgery. }\end{array}$ & 7 & 28 & 15 & 60 & 3 & 12 & 20 & 80 & 4 & 16 & 1 & 4 & $<0.001 * *$ \\
\hline $\begin{array}{l}\text { 6. Measuring vital } \\
\text { signs. }\end{array}$ & 25 & 100 & - & 0.0 & - & 0.0 & 25 & 100 & - & 0.0 & - & 0.0 & - \\
\hline $\begin{array}{l}\text { 7. Complications } \\
\text { after bariatric } \\
\text { surgery. }\end{array}$ & - & 0.0 & - & 0.0 & 25 & 100 & 13 & 52 & 3 & 12 & 9 & 36 & $<0.001 * *$ \\
\hline $\begin{array}{l}\text { 8. Preparations } \\
\text { before bariatric } \\
\text { surgery. }\end{array}$ & 5 & 20 & 9 & 36 & 11 & 44 & 9 & 36 & 14 & 56 & 2 & 8 & $0.015^{*}$ \\
\hline $\begin{array}{l}\text { 9. Exercise carried } \\
\text { out after bariatric } \\
\text { surgery. }\end{array}$ & 2 & 8 & 23 & 92 & - & 0.0 & 16 & 64 & 9 & 36 & - & 0.0 & $<0.001 * *$ \\
\hline $\begin{array}{l}\text { 10. Good diet after } \\
\text { bariatric surgery. }\end{array}$ & - & - & - & - & - & - & - & - & - & - & - & - & \\
\hline $\begin{array}{l}1^{\text {st }} \text { stage : Day 0-3: } \\
\text { Clear liquid diet }\end{array}$ & - & 0.0 & 7 & 28 & 18 & 72 & 5 & 20 & 14 & 56 & 6 & 24 & $<0.001 * *$ \\
\hline $\begin{array}{l}2^{\text {nd }} \text { stage: Day } 4 \text { - 14: } \\
\text { Full liquid diet }\end{array}$ & - & 0.0 & 7 & 28 & 18 & 72 & 5 & 20 & 14 & 56 & 6 & 24 & $0.006 * *$ \\
\hline $\begin{array}{l}3^{\text {rd }} \text { stage: Day 15-35: } \\
\text { Puree diet }\end{array}$ & - & 0.0 & 7 & 28 & 18 & 72 & 5 & 20 & 14 & 56 & 6 & 24 & $<0.001 * *$ \\
\hline $\begin{array}{l}4^{\text {th }} \text { stage: Week } 6 \& \\
\text { Beyond: regular food }\end{array}$ & - & 0.0 & 7 & 28 & 18 & 72 & 5 & 20 & 14 & 56 & 6 & 24 & $<0.001 * *$ \\
\hline $\begin{array}{l}\text { 11. Instructions } \\
\text { followed after } \\
\text { discharge from the } \\
\text { hospital. }\end{array}$ & - & 0.0 & 3 & 12 & 22 & 88 & 16 & 64 & 8 & 32 & 1 & 4 & $<0.001 * *$ \\
\hline
\end{tabular}

Chi-square test used for comparison between percentages

Cc: Complete correct.

Incc: Incomplete correct.

Inc: Incorrect.
(**) Statistically moderate significant $P<0.01$.

(*) Statistically significant $P<0.05$. 
Table (3): Comparison between study and control group as regarded late complications after implementation of nursing guidelines $(n=50)$ :

\begin{tabular}{|c|c|c|c|c|c|c|c|c|c|c|c|c|c|c|c|}
\hline \multirow{3}{*}{$\begin{array}{c}\text { Late } \\
\text { complication }\end{array}$} & \multicolumn{6}{|c|}{ Study $(n=25)$} & \multicolumn{6}{|c|}{ Control $(n=25)$} & \multirow{3}{*}{ P1 } & \multirow{3}{*}{$\mathbf{P 2}$} & \multirow{3}{*}{ P3 } \\
\hline & \multicolumn{2}{|c|}{$1^{\text {st }}$} & \multicolumn{2}{|c|}{$2^{\text {nd }}$} & \multicolumn{2}{|c|}{$\begin{array}{l}\text { After } 6 \\
\text { months }\end{array}$} & \multicolumn{2}{|c|}{$1^{\text {st }}$} & \multicolumn{2}{|c|}{$2^{\text {nd }}$} & \multicolumn{2}{|c|}{$\begin{array}{l}\text { After } 6 \\
\text { months }\end{array}$} & & & \\
\hline & No & $\%$ & No & $\%$ & No & $\%$ & No & $\%$ & No & $\%$ & No & $\%$ & & & \\
\hline Internal hernia & - & - & - & - & - & - & - & - & - & - & - & - & - & - & - \\
\hline $\begin{array}{l}\text { Bowel } \\
\text { obstruction }\end{array}$ & 2 & 8 & 2 & 8 & 1 & 4 & 9 & 36 & 9 & 36 & 8 & 36 & $0.038^{*}$ & $0.038^{*}$ & $0.022 *$ \\
\hline -Abdominal pain & 2 & 8 & 2 & 8 & 1 & 4 & 9 & 36 & 9 & 36 & 8 & 36 & $0.038^{*}$ & $0.038^{*}$ & $0.022 *$ \\
\hline - Distension & 2 & 8 & 2 & 8 & 1 & 4 & 9 & 36 & 9 & 36 & 8 & 36 & $0.038 *$ & $0.038 * *$ & $\begin{array}{c}0.022 * \\
*\end{array}$ \\
\hline -Vomiting, & 2 & 8 & 2 & 8 & 1 & 4 & 9 & 36 & 9 & 36 & 8 & 36 & $0.038^{*}$ & $0.038^{*}$ & $0.022 *$ \\
\hline $\begin{array}{l}\text {-diarrhea or } \\
\text { Constipation }\end{array}$ & 2 & 8 & 2 & 8 & 1 & 4 & 9 & 36 & 9 & 36 & 8 & 36 & $0.038^{*}$ & $0.038^{*}$ & $0.022 *$ \\
\hline $\begin{array}{l}\text { 3-Impaired skin } \\
\text { integrity }\end{array}$ & 2 & 8 & 2 & 8 & 1 & 4 & 9 & 36 & 9 & 36 & 8 & 36 & $0.038^{*}$ & $0.038^{*}$ & $0.022 *$ \\
\hline $\begin{array}{l}\text { Dryness of lips } \\
\text { and tongue }\end{array}$ & 2 & 8 & 2 & 8 & 1 & 4 & 9 & 36 & 9 & 36 & 8 & 36 & $0.038^{*}$ & $0.038^{*}$ & $0.022 *$ \\
\hline - Skin wrinkling & 3 & 12 & 2 & 8 & 1 & 4 & 11 & 36 & 9 & 36 & 7 & 36 & $0.024 *$ & $0.038^{*}$ & $0.042 *$ \\
\hline $\begin{array}{l}\text { Wound } \\
\text { infection }\end{array}$ & 4 & 16 & 2 & 4 & 1 & 4 & 12 & 48 & 9 & 36 & 7 & 28 & $0.031 *$ & $0.038^{*}$ & $0.042 *$ \\
\hline $\begin{array}{l}\text {-Redness and } \\
\text { swollen }\end{array}$ & 4 & 16 & 2 & 4 & 1 & 4 & 12 & 48 & 9 & 36 & 7 & 28 & $0.031 *$ & $0.038^{*}$ & $0.042 *$ \\
\hline -Wound pus & 4 & 16 & 2 & 4 & 1 & 4 & 12 & 48 & 9 & 36 & 7 & 28 & $0.031 *$ & $0.038^{*}$ & $0.042 *$ \\
\hline -Hyperthermia & 4 & 16 & 2 & 4 & 1 & 4 & 12 & 48 & 9 & 36 & 7 & 28 & $0.031^{*}$ & $0.038^{*}$ & $0.042 *$ \\
\hline $\begin{array}{l}\text {-Yellowish and } \\
\text { radish secretions }\end{array}$ & 4 & 16 & 2 & 4 & 1 & 4 & 12 & 48 & 9 & 36 & 7 & 28 & $0.031 *$ & $0.038^{*}$ & $0.042 *$ \\
\hline $\begin{array}{l}\text { Vitamins and } \\
\text { minerals } \\
\text { deficiency }\end{array}$ & 1 & 4 & 1 & 4 & 0 & 4 & 7 & 48 & 7 & 28 & 6 & 24 & $0.042 *$ & $0.042 *$ & $0.027 *$ \\
\hline -Muscle cramps & 1 & 4 & 1 & 4 & 0 & 4 & 7 & 48 & 7 & 28 & 6 & 24 & $0.042 *$ & $0.042 *$ & $0.027 *$ \\
\hline $\begin{array}{l}\text {-Decrease } \\
\text { intellectual } \\
\text { function } \\
\end{array}$ & 1 & 4 & 1 & 4 & 0 & 4 & 7 & 48 & 7 & 28 & 6 & 24 & $0.042 *$ & $0.042 *$ & $0.027 *$ \\
\hline -Fatigue- & 1 & 4 & 1 & 4 & 0 & 0.0 & 6 & 24 & 6 & 24 & 4 & 16 & $0.047^{*}$ & $0.047^{*}$ & $0.117 *$ \\
\hline $\begin{array}{l}\text {-Increase the } \\
\text { sense of } \\
\text { coldness- }\end{array}$ & 1 & 4 & 1 & 4 & 0 & 0.0 & 6 & 24 & 6 & 24 & 4 & 16 & $0.047 *$ & $0.047 *$ & $0.117 *$ \\
\hline -Constipation- & 1 & 4 & 1 & 4 & 0 & 0.0 & 6 & 24 & 6 & 24 & 4 & 16 & $0.047 *$ & $0.047 *$ & $0.117 *$ \\
\hline -Lack of appetite & 1 & 4 & 1 & 4 & 0 & 4 & 7 & 28 & 7 & 28 & 6 & 24 & $0.042 *$ & $0.042 *$ & $0.027 *$ \\
\hline $\begin{array}{l}\text {-Chills of eyelids } \\
\text { and mouth }\end{array}$ & 1 & 4 & 1 & 4 & 0 & 4 & 7 & 28 & 7 & 28 & 6 & 24 & $0.042 *$ & $0.042 *$ & $0.027 *$ \\
\hline $\begin{array}{l}\text { Gall stones } \\
\text { formation }\end{array}$ & - & - & - & - & - & - & - & - & - & - & - & - & - & - & - \\
\hline $\begin{array}{l}\text { 7-Recurrence of } \\
\text { obesity }\end{array}$ & 4 & 16 & 2 & 4 & 1 & 4 & 12 & 48 & 9 & 36 & 7 & 28 & $0.031^{*}$ & $0.038^{*}$ & $0.042 *$ \\
\hline -By BMI- & 4 & 16 & 2 & 4 & 1 & 4 & 12 & 48 & 9 & 36 & 7 & 28 & $0.031^{*}$ & $0.038^{*}$ & $0.042 *$ \\
\hline
\end{tabular}

Chi-square test used for comparison between percentages

P1: Comparison between study and control group in $1^{\text {st }}$

P2: Comparison between study and control group in $2^{\text {nd }}$

P3: Comparison between study and control group after 6 month 
Table (4): Relation between knowledge and socio-demographic data in study group.

\begin{tabular}{|c|c|c|c|c|c|c|c|c|c|c|c|c|c|c|}
\hline & \multicolumn{13}{|c|}{ Study group } & \multirow{4}{*}{$\begin{array}{c}\text { P. } \\
\text { value }\end{array}$} \\
\hline & \multicolumn{6}{|c|}{ Knowledge level before } & \multirow{3}{*}{$\begin{array}{c}P . \\
\text { value }\end{array}$} & \multicolumn{6}{|c|}{ Knowledge level after } & \\
\hline & \multicolumn{2}{|c|}{ Poor } & \multicolumn{2}{|c|}{ Fair } & \multicolumn{2}{|c|}{ Good } & & \multicolumn{2}{|c|}{ Poor } & \multicolumn{2}{|c|}{ Fair } & \multicolumn{2}{|c|}{ Good } & \\
\hline & No. & $\%$ & No. & $\%$ & No. & $\%$ & & No. & $\%$ & No. & $\%$ & No. & $\%$ & \\
\hline \multicolumn{15}{|l|}{ Age groups } \\
\hline $20-<30$ years & 5 & 25.0 & 2 & 40.0 & 0 & 0.0 & \multirow{3}{*}{0.784} & 2 & 33.3 & 1 & 11.1 & 4 & 40.0 & \multirow{3}{*}{0.505} \\
\hline $30-<40$ years & 9 & 45.0 & 2 & 40.0 & 0 & 0.0 & & 2 & 33.3 & 6 & 66.7 & 3 & 30.0 & \\
\hline $40+$ years & 6 & 30.0 & 1 & 20.0 & 0 & 0.0 & & 2 & 33.3 & 2 & 22.2 & 3 & 30.0 & \\
\hline \multicolumn{15}{|l|}{ Sex } \\
\hline Male & 2 & 10.0 & 1 & 20.0 & 0 & 0.0 & \multirow{2}{*}{0.538} & 0 & 0.0 & 1 & 11.1 & 2 & 20.0 & \multirow{2}{*}{0.489} \\
\hline Female & 18 & 90.0 & 4 & 80.0 & 0 & 0.0 & & 6 & 100.0 & 8 & 88.9 & 8 & 80.0 & \\
\hline \multicolumn{15}{|l|}{ Marital status } \\
\hline Single & 5 & 25.0 & 1 & 20.0 & 0 & 0.0 & \multirow{3}{*}{0.594} & 1 & 16.7 & 1 & 11.1 & 4 & 40.0 & \multirow{3}{*}{0.256} \\
\hline Married & 12 & 60.0 & 4 & 80.0 & 0 & 0.0 & & 4 & 66.7 & 8 & 88.9 & 4 & 40.0 & \\
\hline Divorced & 3 & 15. & 0 & 0.0 & 0 & 0. & & 1 & 16.7 & 0 & 0.0 & 2 & 20. & \\
\hline Widow & 3 & 15. & 0 & 0.0 & 0 & 0. & & 1 & 16.7 & 0 & 0.0 & 2 & 20. & \\
\hline \multicolumn{15}{|l|}{ Occupation } \\
\hline Work & 11 & 55.0 & 5 & 100.0 & 0 & 0.0 & \multirow[b]{2}{*}{0.061} & 4 & 66.7 & 6 & 66.7 & 6 & 60.0 & \multirow{2}{*}{0.944} \\
\hline Not work & 9 & 45.0 & 0 & 0.0 & 0 & 0.0 & & 2 & 33.3 & 3 & 33.3 & 4 & 40.0 & \\
\hline
\end{tabular}

Chi-square test used for comparison between percentages

Table (5): Relation between knowledge and socio-demographic data in control group

\begin{tabular}{|c|c|c|c|c|c|c|c|c|c|c|}
\hline & \multicolumn{9}{|c|}{ Control group } & \multirow{4}{*}{ P.value } \\
\hline & \multicolumn{4}{|c|}{ Knowledge level before } & \multirow{3}{*}{$\begin{array}{c}\text { P. } \\
\text { value }\end{array}$} & \multicolumn{4}{|c|}{ Knowledge level after } & \\
\hline & \multicolumn{2}{|c|}{ Poor } & \multicolumn{2}{|c|}{ Fair } & & \multicolumn{2}{|c|}{ Poor } & \multicolumn{2}{|c|}{ Fair } & \\
\hline & No. & $\%$ & No. & $\%$ & & No. & $\%$ & No. & $\%$ & \\
\hline \multicolumn{11}{|l|}{ Age groups } \\
\hline $20-<30$ years & 6 & 28.6 & 2 & 50.0 & \multirow{3}{*}{0.499} & 6 & 31.6 & 2 & 33.3 & \multirow{3}{*}{0.994} \\
\hline $30-<40$ years & 12 & 57.1 & 1 & 25.0 & & 10 & 52.6 & 3 & 50.0 & \\
\hline $40+$ years & 3 & 14.3 & 1 & 25.0 & & 3 & 15.8 & 1 & 16.7 & \\
\hline \multicolumn{11}{|l|}{ Sex } \\
\hline Male & 2 & 9.5 & 0 & 0.0 & \multirow{2}{*}{0.520} & 2 & 10.5 & 0 & 0.0 & \multirow{2}{*}{0.407} \\
\hline Female & 19 & 90.5 & 4 & 100.0 & & 17 & 89.5 & 6 & 100.0 & \\
\hline \multicolumn{11}{|l|}{ Marital status } \\
\hline Single & 8 & 38.1 & 2 & 50.0 & \multirow{4}{*}{0.101} & 7 & 36.8 & 3 & 50.0 & \multirow{4}{*}{0.240} \\
\hline Married & 12 & 57.1 & 1 & 25.0 & & 11 & 57.9 & 2 & 33.3 & \\
\hline Divorced & 1 & 4.8 & 0 & 0.0 & & 1 & 5.3 & 0 & 0.0 & \\
\hline Widow & 0 & 0.0 & 1 & 25.0 & & 0 & 0.0 & 1 & 16.7 & \\
\hline \multicolumn{11}{|l|}{ Occupation } \\
\hline Work & 10 & 47.6 & 2 & 50.0 & \multirow{2}{*}{0.930} & 8 & 42.1 & 4 & 66.7 & \multirow{2}{*}{0.294} \\
\hline Not work & 11 & 52.4 & 2 & 50.0 & & 11 & 57.9 & 2 & 33.3 & \\
\hline
\end{tabular}

Chi-square test used for comparison between percentages 
Table (6): Comparison between early complications and knowledge in study and control group:

\begin{tabular}{|c|c|c|c|c|c|c|c|c|}
\hline \multirow[b]{2}{*}{ Early complications } & \multicolumn{3}{|c|}{ Study } & \multirow[b]{2}{*}{ P. value } & \multicolumn{3}{|c|}{ Control } & \multirow[b]{2}{*}{$\begin{array}{c}\text { P. } \\
\text { value }\end{array}$} \\
\hline & $\begin{array}{l}\text { Poor } \\
(n=6)\end{array}$ & $\begin{array}{c}\text { Fair } \\
(\mathbf{n}=9)\end{array}$ & $\begin{array}{c}\text { Good } \\
(\mathbf{n}=10)\end{array}$ & & $\begin{array}{c}\text { Poor } \\
(\mathbf{n}=19)\end{array}$ & $\begin{array}{c}\text { Fair } \\
(\mathrm{n}=6)\end{array}$ & $\begin{array}{l}\text { Good } \\
(\mathbf{n}=\mathbf{0})\end{array}$ & \\
\hline Internal bleeding & 0 & 0 & 0 & - & 0 & 0 & 0 & - \\
\hline External bleeding & 2 & 0 & 0 & $0.032 *$ & 7 & 2 & 0 & 0.876 \\
\hline Respiratory failure & 0 & 0 & 0 & - & 0 & 0 & 0 & - \\
\hline Pulmonary embolism & 0 & 0 & 0 & - & 0 & 0 & 0 & - \\
\hline postoperative leakage & 5 & 1 & 0 & $0.001 * *$ & 19 & 3 & 0 & $0.001 * *$ \\
\hline Deep venous thrombosis & 0 & 0 & 0 & - & 0 & 0 & 0 & - \\
\hline Splinic injury & 0 & 0 & 0 & - & 0 & 0 & 0 & - \\
\hline
\end{tabular}

Table (7): comparison between late complications and knowledge in study and control group:

\begin{tabular}{|c|c|c|c|c|c|c|c|c|c|c|c|c|c|c|c|c|c|c|c|c|}
\hline \multirow[b]{3}{*}{ Late complications } & \multicolumn{9}{|c|}{ Study $(n=25)$} & \multirow{3}{*}{ 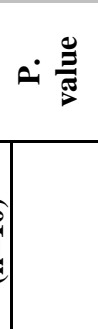 } & \multicolumn{9}{|c|}{ Control $(n=25)$} & \multirow{3}{*}{ 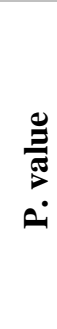 } \\
\hline & \multicolumn{3}{|c|}{$1^{\text {st }}$} & \multicolumn{3}{|c|}{$2^{\text {nd }}$} & \multicolumn{3}{|c|}{$\begin{array}{l}\text { After } 6 \\
\text { months }\end{array}$} & & \multicolumn{3}{|c|}{$1^{\mathrm{st}}$} & \multicolumn{3}{|c|}{$2^{\text {nd }}$} & \multicolumn{3}{|c|}{$\begin{array}{l}\text { After } 6 \\
\text { months }\end{array}$} & \\
\hline & 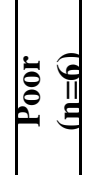 & 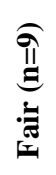 & 送 & $\begin{array}{l}\text { ô } \\
\stackrel{11}{\Xi} \\
\dot{0} \\
\stackrel{0}{0}\end{array}$ & 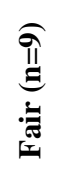 & 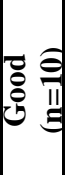 & 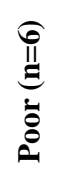 & 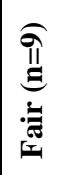 & 它 & & $\div$ 의 & 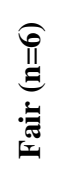 & 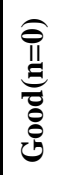 & ؛ & 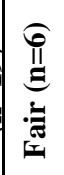 & 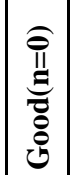 & 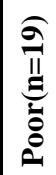 & 菖 & 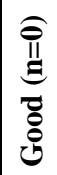 & \\
\hline Internal hernia & 0 & 0 & 0 & 0 & 0 & 0 & 0 & 0 & 0 & _ & 0 & 0 & 0 & 0 & 0 & 0 & 0 & 0 & 0 & - \\
\hline Bowel obstruction: & 2 & 0 & 0 & 2 & 0 & 0 & 1 & 0 & 0 & $\begin{array}{l}1.0 \\
00\end{array}$ & 8 & 1 & 0 & 8 & 1 & 0 & 8 & 0 & 0 & $\begin{array}{c}0.6 \\
18\end{array}$ \\
\hline $\begin{array}{l}\text { Impaired skin } \\
\text { integrity: }\end{array}$ & 2 & 0 & 0 & 2 & 0 & 0 & 1 & 0 & 0 & $\begin{array}{l}1.0 \\
00\end{array}$ & 7 & 2 & 0 & 8 & 1 & 0 & 8 & 0 & 0 & $\begin{array}{l}0.3 \\
58 \\
\end{array}$ \\
\hline Wound infection: & 3 & 1 & 0 & 2 & 0 & 0 & 1 & 0 & 0 & $\begin{array}{l}0.6 \\
46\end{array}$ & $\begin{array}{l}1 \\
0\end{array}$ & 2 & 0 & 9 & 0 & 0 & 7 & 0 & 0 & $\begin{array}{l}0.2 \\
38\end{array}$ \\
\hline $\begin{array}{l}\text { Vitamins and } \\
\text { minerals deficiency }\end{array}$ & 1 & 0 & 0 & 1 & 0 & 0 & 0 & 0 & 0 & $\begin{array}{l}1.0 \\
00\end{array}$ & 6 & 1 & 0 & 6 & 1 & 0 & 6 & 0 & 0 & $\begin{array}{l}0.6 \\
21\end{array}$ \\
\hline $\begin{array}{l}\text { Gall stones } \\
\text { formation: }\end{array}$ & 0 & 0 & 0 & 0 & 0 & 0 & 0 & 0 & 0 & - & 0 & 0 & 0 & 0 & 0 & 0 & 0 & 0 & 0 & - \\
\hline $\begin{array}{l}\text { Recurrence of } \\
\text { obesity }\end{array}$ & 3 & 1 & 0 & 2 & 0 & 0 & 1 & 0 & 0 & $\begin{array}{l}0.6 \\
46\end{array}$ & 9 & 3 & 0 & 9 & 0 & 0 & 7 & 0 & 0 & $\begin{array}{l}0.1 \\
06\end{array}$ \\
\hline
\end{tabular}

Table (8): Pre and postoperative total score level of knowledge for patients about bariatric surgery for both study and control group:

\begin{tabular}{|l|c|c|c|}
\hline \multirow{2}{*}{ variables } & \multicolumn{2}{|c|}{$\begin{array}{c}\text { Knowledge score (mean } \pm \text { SD) } \\
\text { Total score }=\mathbf{4 5}\end{array}$} & \multirow{2}{*}{ P. value } \\
\cline { 2 - 3 } & Pre & Post & \\
\hline Study & $9.1 \pm 3.9 \mathrm{~s}$ & $29.8 \pm 6.2$ & $<0.001^{* *}$ \\
\hline Control & $7.4 \pm 3.5$ & $8.4 \pm 3.5$ & $0.334^{\text {ns }}$ \\
\hline P. value & $0.112^{\mathrm{ns}}$ & $<0.001^{* *}$ & \\
\hline
\end{tabular}

Table (1): this table demonstrates that; as regarded age, the sample of study and control group was (35.6 \pm 9.5 and 32.6 \pm 6.9$)$ respectively. As regarded sex, the majority of sample in study and control group were female (88\% and 92\%) respectively. As regarded marital status the majority of sample in study and control group was married $(64.0 \%$ and
$52.0 \%)$ respectively. As regarded educational level, all of the sample in study and control group were read and write $(92.0 \%$ and $100 \%)$ respectively. As regarded occupation, more than half in control group did not work $(52.0 \%)$ while about two third of study group was work $(64.0 \%)$. There is no statistically 
significant difference in all of bio-socio-demographic data.

Table (2): this table shows that; there was statistically significant difference as regarded pre and postoperative score for level of knowledge of study group about bariatric surgery except the following: important of the efficiency of vital signs, knowledge about postoperative complications, exercise carried out and good diet after operation.

Table (3): this table demonstrates that; there was statistical significant difference between study and control group as regarded late complications.

Table (4): this table shows that there; there was statistical significant difference between knowledge and sociodemographic data in study group.

Table (5):this table shows that there; there was statistical significant difference between knowledge and sociodemographic data in control group.

Table (6): this table shows that there; there was statistical significant difference between knowledge and early complications in study and control group.

Table (7): this table shows that there; there was statistical significant difference between knowledge and late complications in study and control group.

Table (8):this table shows that there; there were statistically significant difference in pre and postoperative total score level of knowledge for patients about bariatric surgery for both study and control group (total mean scre $=45$ ).

\section{Discussion}

This work aims to assess knowledge of patient with bariatric surgery, develop nursing guidelines to minimize postoperative complications of bariatric surgery and evaluate the impact of nursing guidelines on minimizing postoperative complications of patients with bariatric surgery.

Regarding bio-socio-demographic characteristics, two groups (study and control) were included in this study with no statistically significant differences shown between age, sex, BMI, marital status, the level of education and occupation at the beginning of the study.

The present study findings showed that as regarded age, the mean of a sample of study and control group was (35.6 \pm 9.5 and $32.6 \pm 6.9)$ respectively this result disagrees with (Athyros et al., 2011) who mentioned that; sixty-five participants (41 women and 24 men) with a mean age of 51.5 years.

As regarded BMI the present study stated that the sample of study and control groups were (51 \pm 9.5 and $49 \pm 7.5$ ) respectively. This result agrees with (Dumas et al., 2014) who mentioned that; a patient who performed bariatric surgeries with a mean BMI of more than 45 .
As regarded BMI and chronic diseases the present study agrees with (Damschoder et al., 2011) who reported that patients with extremely high BMIs $(>50)$ and/or a high burden of comorbidities have a greater risk of death after surgery, compared to patients with lower BMIs and lesser comorbidity burdens.

Concerning sex, the present study showed that the majority of sample in study and control group were female, this result agrees with (Robitaille, 2012) who mentioned that; the procedure is producing some significant results that were published in a recent study in bariatric times and are based on postoperative outcomes for 66 patients (44 female).

The result in the present study revealed that as regarded type of operation more than two third of study and control groups were performed gastric bypass and this study agrees with (Buchwald \& Oien, 2013) who discussed that the gastric bypass surgery is safe than other types of surgery so it is the most performing surgery to the patient. He mentioned the advantages of gastric bypass as; produces significant long-term weight loss (60 to 80 percent excess weight loss), restricts the amount of food that can be consumed, may lead to conditions that increase energy expenditure, produces favorable changes in gut hormones that reduce appetite and enhance satiety and typical maintenance of $>50 \%$ excess weight loss.

This result stated that there were postoperative complications of bariatric surgery occur before implementation of nursing teaching guidelines. This result is in the same line of (McGuire et al., 2011) who mentioned that; complications occur in about 20 percent of bariatric surgical cases, 6 complications resulting from bariatric surgery include the usual risks of any surgical procedure before teaching the patient about diet and exercise, such as anesthesia problems, bleeding, and cardiovascular events incurred while on the operating table or in the early postoperative period (myocardial infarction, deep vein thrombosis, pulmonary embolism). Other complications soon after surgery include nausea and vomiting, incisional hernias, wound infections, strictures, stomach ulcers, stomach and intestine leaks or ruptures, and bowel obstruction. He mentioned that these complications don't appear after teaching the patient about diet and exercise.

The present study mentioned that; the effect of nursing guidelines on minimizing the postoperative complications of bariatric surgery and this agrees with (Mechanic et al., 2013) who mentioned that; patients who received those guidelines were improved and there is a decrease in the incidence of postoperative complications. 
The present study shows that according to knowledge and sociodemographic data; married and work females have more knowledge about bariatric surgery and this agrees with(Miras et al., 2014)who mentioned that females have more knowledge than males about bariatric surgery.

The present study showed that the importance of guidelines on minimizing postoperative complications. This result agrees with (Asher et al., 2013) who compared symptoms before guidelines and 6 months after guidelines, found improvement in functional symptoms, such as abdominal distension, abdominal pain, flatus, and fecal urgency.

The result in the present study revealed that, a great improvement in the knowledge score levels obtained by patients after implementation of nursing guidelines, the majority of sample in study and control groups were poor before implementation nursing guidelines while after implementation of nursing guidelines, most of sample in study group was improved. The present study is in the lines of (Miller et al., 2013) who stated that the guidelines recommend before bariatric surgery as the most beneficial and cost-effective management for motivated individuals with severe obesity.

\section{Conclusion}

Based on the result of the present study, it can be concluded that; the early complications in the study group were significantly better than those in the control group. There was significant difference in improvement throughout the nursing guidelines among the study group existed between late complications for both groups at time of follow-up.

\section{Recommendations}

Based on results of the present study, the following can be recommended

For patients

- Patients who have had bariatric surgery require additional verbal and written information about guidelines for diet and physical activity using pamphlets and simply illustrated nursing guideline booklet to prevent the postoperative complications.

- Preparation and provision of information should start from the time of the surgeon's decision that surgery is required. The patients must visit the plastic surgery unit 2 weeks prior to surgery for the preoperative work up; to prepare them and provide information in the form of booklets, videos, and one to one counseling sessions.

\section{For research (future study)}

- Importance of doing separate studies of bariatric surgery in males and females and will helpfully lead to more effective and preventive - based strategies for future.

- Studies should be done for those patients who high risk for complications after bariatric surgery and apply the preventive measures.

- Survey of incidence of complications after bariatric surgery should be done in order to recognize the prevalence of the problem all over Egypt.

- Replication of the current study on larger probability sample is recommended to achieve generalized ability and wider utilization of the designed program.

\section{References}

1. Arterburn D., Olsen M., Smith V., Livingston E., Van Scoyoc L., Yancy W., \&Maciejewski M., (2015): Association between bariatric surgery and long-term survival. JAmA, 313(1), 62-70.

2. Asher R., Burrows T., \& Collins C., (2013): Very-low-energy diets for weight loss in adults: A review. Nutrition \& Dietetics, 70(2), 101-112.

3. Athyros V G., Tziomalos K., Karagiannis A., \&Mikhailidis D., (2011): Cardiovascular benefits of bariatric surgery in morbidly obese patients. obesity reviews, 12(7), 515-524.

4. Buchwald H., \& Oien D., (2013): Metabolic/bariatric surgery worldwide 2011. Obesity surgery, 23(4), 427-436.

5. Contreras J., Santander C., \& Bravo J., (2013): Correlation between age and weight loss after bariatric surgery. Obesity surgery, 23(8), 1286-1289.

6. Damschoder L., Goodrich D., Robinson C., Fletcher C., \& Lowery J., (2011): A systematic exploration of differences in contextual factors related to implementing the MOVE! weight management program in VA: a mixed methods study. BMC health services research, 11(1), 1.

7. Dumas A., Robitaille J., \&Jette S., (2014): Lifestyle as a choice of necessity: Young women, health, and obesity. Social Theory \& Health, 12(2), 138-158.

8. Horwitz D., Saunders J., Ude-Welcome A., \& Parikh M., (2015): Insurance-mandated medical weight management before bariatric surgery. Surgery for Obesity and Related Diseases.

9. Marquez B., Ayala G., \& Wing R., (2015): Acculturation and weight loss strategies among 
Latinas. Journal of Immigrant and Minority Health, 17(2), 610-

10. McGuire S., (2011): Shields M., Carroll MD, Ogden CL adult obesity prevalence in Canada and the United States. NCHS data brief no. 56, Hyattsville, MD: national Center for Health Statistics, 2011. Advances in Nutrition: An International Review Journal, 2(4), 368-369.

11. Mechanick J., Youdim A., Jones D., Garvey W., Hurley D., McMahon, M., \& Dixon J., (2013): Clinical practice guidelines for the perioperative nutritional, metabolic, and nonsurgical support of the bariatric surgery patient-2013 update: Cosponsored by American association of clinical endocrinologists, The obesity society, and American society for metabolic \& bariatric surgery*. Obesity, 21(S1), S1-S27.

12. Mechanick J., Kushner R., Sugerman H., Gonzalez-Campoy J., Collazo-Clavell M., Guven S., \&Sarwer D., (2010): American Association of Clinical Endocrinologists, The Obesity Society, and American Society for Metabolic \& Bariatric Surgery Medical Guidelines for Clinical Practice for the Perioperative Nutritional, Metabolic, and Nonsurgical Support of the Bariatric Surgery Patient. SurgObesRelat Dis, 6(1), 112

13. Miller K., Wischmeyer P., Taylor B., \& McClave S., (2013): An evidence-based approach to perioperative nutrition support in the elective surgery patient. Journal of Parenteral and Enteral Nutrition, 37(5 Suppl), 39S-50S.

14. Miras A., Risstad H., Baqai N., Law S., Søvik T., Mala T., \& le Roux C., (2014): Application of the International Diabetes Federation and American Diabetes Association criteria in the assessment of metabolic control after bariatric surgery. Diabetes, Obesity, and Metabolism, 16(1), 86-89.

15. Noria S., (2013): Biological effects of bariatric surgery on obesity-related comorbidities. Canadian Journal of Surgery, 56(1), 47.

16. Ogden C., Carroll M., Kit B., \&Flegal K., (2012): Prevalence of obesity and trends in body mass index among US children and adolescents, 1999-2010. Jama, 307(5), 483-490.

17. O'Brien P., MacDonald L., Anderson M., Brennan L., \& Brown W., (2013): Long-term outcomes after bariatric surgery: fifteen-year follow-up of adjustable gastric banding and a systematic review of the bariatric surgical literature. Annals of surgery, 257(1), 87-94.
18. Pepino M., Stein R., Eagon J., \& Klein S., (2014): Bariatric surgery-induced weight loss causes remission of food addiction in extreme obesity.Obesity, 22(8), 1792-1798.

19. Robitaille J., (2012): body and capital: underprivileged women ${ }^{\text {ee }} \mathrm{s}$ relation with health and obesity (Doctoral dissertation, University of Ottawa). 